\title{
TRANSNATIONAL ANTI-WAR ACTIVISM: SOLIDARITY, DIVERSITY AND THE INTERNET IN AUSTRALIA, BRITAIN AND THE UNITED STATES AFTER 9/11
}

\author{
Authors' post-print: This is an electronic version of an article published in Australian Journal of Political \\ Science 43(1): 59-73, 2008. Australian Journal of Political Science is available online at: \\ www.tandfonline.com/doi/abs/10.1080/10361140701842573.
}

\section{Kevin Gillan}

Sociology, School of Social Sciences, The University of Manchester.

\section{Jenny Pickerill}

Department of Geography, Leicester University.

Final submission: $13^{\text {th }}$ November 2007

Biographical details:

Kevin Gillan recently completed a doctorate in Politics at the University of Sheffield on the impact of ideological traditions on contemporary social movements contesting globalisation and war. He is now a Lecturer in Sociology at the University of Manchester.

Jenny Pickerill is Lecturer in Human Geography at the University of Leicester. Her most recent book is Cyberprotest: Environmental Activism Online (2003) and she has written over a dozen journal articles on Internet activism. 
TRANSNATIONAL ANTI-WAR ACTIVISM: SOLIDARITY, DIVERSITY AND THE INTERNET IN AUSTRALIA, BRITAIN AND THE UNITED STATES AFTER 9/11

\section{Abstract}

The upsurge in activism opposing wars and occupations in Afghanistan and Iraq appears to represent a significant process of transnational collective action. Using data collected through participant observation, interviews and website analysis this paper explores the role of the Internet in facilitating transnational activism between Australia, Britain and the United States. This research confirms Tarrow's (2005a) assertion of 'rooted cosmopolitanism' - a primary commitment to locally contextualised action combined with a desire for transnational support. The Internet is used primarily for gathering news and for sharing symbolic expressions of solidarity. In Australia in particular, with fewer domestic anti-war resources online, international networking proves particularly useful. To an extent, online networks reach across both political diversity and geographical boundaries. However, online resources do not appear to enable the more personal connections required to build stable, working coalitions across borders. 


\section{Introduction: the Internet and Transnational Activism}

One of the most striking features of popular politics in the post-9/11 world has been the emergence of large-scale anti-war activism in many countries (Figure 1). Making similar arguments in a wide range of political contexts, anti-war campaigns may have moved into the realm of transnational collective action. The latter is defined as a 'coordinated international campaigns on the part of networks of activists against international actors' (della Porta and Tarrow 2005, 2-3). Even where a formal international organisation or coalition does not exist, transnational action may occur. Such activism is likely to include material or ideological linkages made between groups at national and local levels as well as informal ties between grassroots groups. Tarrow claims that transnational collective action is formed by 'rooted cosmopolitans', 'who grow out of local settings and draw on domestic resources'; they engage in transnational activism through 'intertwined networks of a complex international society.... accelerated by increasing connections across borders' $(2005 b, 1)$.

\section{[Figure 1 about here]}

In so far as the Internet offers a relatively inexpensive and highly efficient means of transcending geographical boundaries it likely facilitates transnational collective action. This paper explores the rise of transnationalism in the anti-war protest arena, particularly examining the extent to which it is facilitated by the use of Internet technologies.

In general, political participation is enhanced by information and communication technologies (ICTs) through, for example: faster interaction, sharing of strategies and 
tactics across large distances, low cost dissemination of information and interactive creation of news and commentary (Bennett, 2003; Norris, 2002; Bimber, 2003; Chadwick, 2006). Of course, the Internet is by no means a panacea for the problems activists' face. Activists have shown concern about uneven accessibility, surveillance, unknowable and diffuse audiences, a lack of personal engagement and difficulties in building trust online (Pickerill, 2003).

Further to general findings about use of ICTs in activism, there is evidence that participation in the latest anti-war movements has been boosted by activists' Internet practices (Nah, Veenstra and Shah 2006). Bennett and Givens' survey of participants in a number of major anti-war protests across America demonstrates that Internet technologies have become central to protesters' daily activity. The more central the Internet has come to political activism, the more it has become the route through which individuals first experience key collective actors. At least in the US, those most central to the anti-war movement are 'disproportionately likely to rely on digital communications media' and those with close movement affiliations 'overwhelmingly received their information about the Iraq crisis through e-media' (Bennett and Givens 2006, 1, 17). Furthermore, if new ICTs have enabled participation in recent anti-war activism, then, it is likely that the Internet has also helped the anti-war movement cross borders. Indeed, one activist argues,

The US and British lefts are historically quite separated... [they] don't communicate much, two lefts separated by a common language. With the Internet, all that's changed. (Mike Marqusee interview, writer and activist, London) 
The following sections of this paper present a multi-method analysis of the role of Internet technologies in connecting anti-war movements in three countries. Utilising hyperlink analysis we examine the structure of information resources created by anti-war website authors' linking practices. We illustrate the different positions that different kinds of organisations' websites inhabit within that structure and thereby offer an account of the various informational pathways through which activists may travel. However, we are wary of making further inferences from the quantitative analysis of hyperlinks. We therefore use a qualitative dataset in order to explore the meanings that Web use has for individual activists. This combination of data enables a thorough empirical exploration of the claim that Internet communication aids transnational collective action.

\section{Three Anti-War Movements}

Our three case countries - the US, Britain and Australia - were all key members of the 'coalition of the willing' that invaded Iraq in March 2003 and continue to represent the three largest military interventions in that country (GlobalSecurity.org 2006a, 2006b). We assume that this direct connection with events, combined with wider similarities such as common languages, similar histories of radical protest against the excesses of capitalism, and commitment to liberal democracy and legitimate protest, increase the likelihood of transnational collective action across these countries. In addition, there is a strong possibility for using the Internet to forge such connections since each country has high Internet access and usage rates (International Telecommunications Union 2006).

The rapid spread of anti-war activism immediately after 9/11 may be partially explained through the coming together of a politically diverse range of long-standing 
organisations into coalitions of opposition (Gillan 2006). In Britain activists met on 21 September 2001, forming the Stop the War Coalition (StWC), which has been central to mobilisation against the war on terror ever since. In the US, ANSWER (Act Now to Stop War and End Racism) took an early leading role in organising demonstrations but faced 'massive discontent ... [because] they were just bloody sectarian, high handed and undemocratic' (Mike Marqusee interview), leading to a new national coalition - United for Peace and Justice (UFPJ) - being rapidly formed (Gupta 2006; Meyer and Corrigan-Brown 2005). In Australia, organisations opposing the war on terror appeared at the state level although no national coalition emerged (Morrow 2003).

The demographic composition of these movements generally reflected that of earlier peace campaigns. In Britain this meant they tended to be composed of highly politicised, secular, left-leaning individuals with high levels of education and professional status (Rüdig and Eschle 2003). However, the increase in scale seen especially towards the end of 2002, resulted from the involvement of many new and reactivated participants (Sloboda and Doherty, 2004). Bennet and Givens (2006) found that some 30\% of participants at anti-war demonstrations in New York, San Francisco and Seattle were on their first demonstration. Additionally, British anti-war activism saw the inclusion of increasingly assertive British Muslims. This affected the framing of demands within the movement, with multiple demands being made within large demonstrations (Figure 2). Since the anti-war movements opposed the war on terror in general, and because Muslims were perceived to be at particular risk from both new anti-terror legislation and heightened public anxiety, the new alliances between anti-war protesters and Muslim groups made sense. In Britain there were public calls to 'Stop the Racist Backlash' and StWC organised conferences on 
Islamaphobia. In Australia groups linked the introduction of new anti-terror legislation to the rise of anti-Muslim racism (see Figure 3). US activists made use of the dominant post911 cultural theme of patriotism; a tactic described by Maney, Woehrle \& Coy (2005) as 'harnessing hegemony'. Thus, slogans such as 'dissent is patriotic' (Figure 4) and protests that referred explicitly to the deaths of American soldiers connected to the prevailing mood of national pride (Figure 5).

[Figure 2 about here]

[Figure 3 about here]

[Figure 4 about here]

[Figure 5 about here]

The high point of transnational coordination occurred on 15 February 2003 when between six and ten million people marched in 600 cities across the globe. In London, one million protesters formed the biggest demonstration in British history. In the US 100,000 people protested in New York and 200,000 in San Francisco, and Australia saw 500,000 join demonstrations in six state capitals (BBC, 2003). Such demonstrations have been periodically repeated in all three countries since, albeit with falling turnouts that, to some extent, tracked changing public opinion. As war began 59\% of Americans supported military action, only 39\% Britons felt the same way. After 4 months at war support increased so that $61 \%$ of the British and $74 \%$ of Americans felt it was right to use military force in Iraq (Pew Research Center 2003a, 2003b). Yet by 2006 51\% of Americans believed it was the wrong decision to take military action in Iraq (Pew Research Center, 2007) and in Australia 55\% opposed the war (Grattan, 2006). Tactically, the national demonstrations 
were only part of the story. Britain, for instance, saw a range of direct actions targeting military installations across the country and Australian activists protested the Joint Defence Facility military tracking station at Pine Gap and opposed the Sea Swap programme set up to support US Navy personnel.

\section{Integrating Anti-war Movements Online}

The anti-war activities described above were organised by a range of groups, some long-standing and others new. Within the British and American national coalitions, resources - including money, personnel, trust and political backing - were negotiated and shared. Beyond such formal and relatively stable arrangements, however, there existed an uneven web of connections between a wider range of international, national and local groups that planned protest together and often had overlapping memberships. While we would expect formal connections to be represented via hyperlinks between the relevant groups' websites they are not necessarily expected to reflect the full extent of wider offline network ties. The examination of offline networks typically identifies individual or collective actors as nodes, which are tied by the flow of information or resources between them. Online hyperlink networks, conversely, have informational resources at the nodes while ties represent the potential flow of individuals among those resources. Online networks cannot, therefore, be automatically understood as proxies for offline networks. In particular contexts the relationship between offline and online connections may be stronger (c.f. Ackland and Gibson's (2006) analysis of links between formal political parties). In the context of this study, however, we assume hyperlinks to be indicative primarily of website authors' intent to make their audiences aware of particular 
information. Networks of hyperlinks offer routes through the informational field, which activists may follow. The experience of the movement as constituted on the Web is thereby structured by website authors' decisions concerning which sites to link to. In the following it is precisely that structuring of the information environment on which we focus. In particular we investigate the characteristics and interrelations of three separate hyperlink networks stemming from key anti-war websites in each of Australia, Britain and the US.

\section{Method}

It is possible to identify, follow and analyse hyperlink networks using a software tool called Issue Crawler created by Richard Rogers and colleagues. ${ }^{1}$ The founding assumption is that a hyperlink between sites indicates an association of content, that the sites are at least in part, oriented to the same issue. The analysis begins with the selection of a 'seed set' of relevant URL's, in this case 11 prominent anti-war websites from each country were included (total seed set $=33$ ). These sites are then used to identify the sites constituting the issue networks. The Issue Crawler visits each site in the seed set, 'reading' the content of the homepage and examining, firstly, internal hyperlinks. The software follows internal hyperlinks to a depth of two; that is, it downloaded each page of the site that was accessible through one or two 'clicks' from the homepage. The software records all external hyperlinks contained in each visited page, compiling a list of linked websites. ${ }^{2}$ Through visiting every

\footnotetext{
1 The software is available at www.issuecrawler.net; see Rogers 2002 for a description of the software; Rogers and Marres 2000, for an interesting application.

2 A website is defined here by domain name, thus 'internal hyperlinks' refer to pages with the same domain name (e.g. stopwar.org.uk), and 'external hyperlinks' refer to pages with different domain names.
} 
site in the seed set, Issue Crawler utilises 'co-link analysis' to identify a resulting 'issue network'. At this stage any webpage in the complied list that had only one hyperlink reference from another site in the network is removed. Sites that received links from two or more other sites (that is, were 'co-linked') are considered as members of the issue network. The procedure is then reiterated using the new list of co-linked sites. Reiteration reduces the bias exerted by the researcher's choice of websites for the seed set; yet, on the grounds that co-link analysis ensures some commonality of content, ensures that the network remains rooted to the originally identified issue. ${ }^{3}$

In addition to delineating the issue network, Issue Crawler also provides data on the links between sites. In particular it records the number of links received by each website from other members of the issue network. This figure provides an estimate of the centrality of each site in that those websites that receive the most links from other websites in the network have the greatest probability of a user visiting them if they start browsing from any other point in the network.

The sites included in each of the seed sets were identified via knowledge of the most prominent offline anti-war movements in each country. As well being clearly identified with

\footnotetext{
3 The number of hyperlinks to follow in an issue network is potentially vast and Issue Crawler visited over 58,000 individual webpages across our three networks. Networks for analysis are limited, therefore, to a maximum of one hundred websites (domains) at each stage of co-link analysis. Since the one hundred websites carried to further analysis are those with the greatest number of in-links from webpages identified elsewhere in the network, and because the following arguments do not depend on the absolute number of websites in each network, this software limitation is not problematic.
} 
the anti-war effort, the sites needed to meet two further specific criteria to be included in the seed set: (1) they needed to display an explicit orientation/bias to the relevant case country; and (2) they also needed to explicitly advocate activities outside of the sphere of institutional politics. Social movements are typically defined by a preference towards noninstitutional collective action and by their characteristic claims and framings (della Porta and Diani 1999: 15-25). These criteria thereby reflect our ambition to study social movements opposing the war on terror, rather than the wide array of different forums in which these issues have been discussed. A total of 33 seed sites were identified, with 11 seed sites per country (see Appendix 1).

To extend the depth and reliability of our analysis we manually coded the content of the websites. The homepage and linked internal pages of each site in each network were reviewed and coded on two dimensions. 'Locale' coding reflected the national focus of content of each website and was used to investigate the level of transnationalism evident in the networks. Coding of 'website purpose' was designed to examine the extent to which networks were involved in promoting activities and issues beyond the anti-war focus. More detail on the specific coding categories on each dimension are provided below, following the overall network profiles.

\section{Network Overviews}


By running Issue Crawler separately for each seed set, we identified three issue networks, each consisting of slightly fewer than one hundred websites. ${ }^{4}$ As Figure 6 illustrates, there was some overlap between the three resulting issue networks; that is, some high visibility sites were discovered in more than one of these networks.

\section{[figure 6 about here]}

Ten sites were found to exist in all three networks and a further 26 websites were found in two of the networks. Nevertheless, there remained a strong degree of national clustering with 221 out of a total of 257 websites being found in only one network. In this regard it seems that the Web is a long way from transcending the importance of national boundaries. Among those sites that do provide interconnections between national networks (i.e. those located in the overlap zones in figure 6) more are linked into the Australian network. Exclusive overlap between the British and US networks is low ( 5 sites) with both of these networks sharing twice that number of websites exclusively with Australia. This suggests more internationally oriented hyperlink practices within the Australian online anti-war network.

\section{[Table 1 about here]}

Table 1 presents an overview of each issue network. The three data columns present three separate network analyses. Where a site was present in more than one network their in-links were re-calculated for that network. As a result these overlap sites have different

\footnotetext{
${ }^{4}$ The identified networks all reached the software limit of 100 websites per network. However, cleaning of the data to remove websites that were still linked to but no longer existed (and therefore unavailable for manual coding), marginally reduced network size.
} 
in-link counts depending on which network they are considered to be part of, given the changing nature of the surrounding sites. The raw in-link counts indicate that the US network is the most densely connected and Australia the least. The standardized scores (mean in-link counts) confirms this, showing that on average a US organisation in the network is linked to by 14 other websites while in the Australian network the figure is almost half that total. US network density is also reflected by the scores recorded for individual sites within it. The UFJP website records the highest number of in-links of any site in any of the networks, with over $50 \%$ of sites linking to it. Interestingly, however, the network produced from the Australian seed set also shows the UFPJ website to be its most highly in-linked site. Further analysis of the content of the UFPJ website reveals that it represents an organisation that is clearly American in both its location and its focus. The large number of Australian sites linking to UFPJ may reflect the lack of an Australian national coalition offline, which might otherwise have provided a central information point online.

\section{Analysis of Locales}

The Venn diagram presented in Figure 6 above examined the degree of overlap across the networks, with websites counted simply as 'belonging' to the national network(s) in which they were found after the analytical process had been completed for each of the three seed sets. Finding an overlap between the networks, however, implies that some sites were either included in the networks of countries to which they were not oriented, or had a genuinely transnational locale. Rather than rely on domain names or hosting location, therefore, we engaged in manual coding of every website to define its geographic locale. Coding took account of the locations of advertised events, the subjects of 
political critique and the addresses provided for correspondence with the organisation represented by that site. Where all three of these elements were clearly oriented to one country, it was easy to identify the appropriate locale. The locale was identified as 'international' if there was evidence that it had organised events or activities, or was administratively supported, in more than one country. Table 2 represents the findings on overlap based on the manual coding of locale for each site.

\section{[Table 2 about here]}

The left-hand side of Table 2 considers each of the three networks separately. The findings confirm the generally limited degree of overlap reported in Figure 6. The table shows each national network to be biased towards websites with locales in that nation. However, the strength of this bias varies considerably across networks. The US network is the most homogenous with the vast majority of sites having an American locale. The British network is somewhat looser, with just over half of sites having a British locale. The Australian network, however, is the most geographically heterogenous, with less than half of its network being focused on Australia. The British network shows the strongest inclusion of internationally operating websites (such as the global nuclear disarmament network Abolition 2000) while the Australian network contains the largest proportion of sites focused on nations other than its own (such as UFPJ or Veterans for Peace, both focused on the US). In total we find 37 sites (39.8\%) out of the Australian online anti-war network are focused on single nations other than Australia.

The right-hand side of Table 2 compares those sites that appeared in more than one network, with the majority that did not. Thus we can consider what differentiates sites that 
gain international recognition (as expressed through position in the overlap zones) with those that do not. Confirming our previous point, we see that none of the overlap websites have an Australian locale, whereas over 50\% have a US locale. So, while overlap between national anti-war networks may represent a form of transnationalism, it is a form that is dependent on the high profile of sites within the US issue network.

\section{Analysis of Website Types}

Coding categories for 'website type' were developed after an initial examination of the three issue networks. The categories were based around identifying the general orientation or purpose of the authors or owners of the site (as represented in the site contents) and, in the case of activist groups, their approach to political action. This approach resulted in the following seven website types being identified:

(1) Peace protest sites - articulated a strong commitment to values of peace, i.e. anti-war, pro-nuclear disarmament, anti-arms trade etc. The sites either described the site authors/owners involvement in non-institutional political activity such as mass demonstrations or direct action, or they promoted such activities.

(2) Peace lobby sites - contained a similar value/issue focus to protest sites but the political activities described or promoted were more institutionalised, taking the form of direct lobbying of institutions of governance, or writing letters to elected representatives. Sites that were purely informational resources on peace were also included in this category.

(3) 'Wider' protest and (4) lobby sites - followed the above distinctions respectively in terms of their orientation to action but had a multiple issue foci or a primary focus 
on an issue area other than peace/anti-war such as human rights or the environment.

(5) Alternative media and movement support services - included non-mainstream media news and information sources (from Indymedia to a range of weblogs) and websites that offered online services such as website hosting or electronic petitions.

(6) Mainstream media sites - included established offline news outlets such as television channels (e.g. CNN) or newspapers (e.g. The Guardian).

(7) Governance sites - included institutions of national government (e.g. Ministry of Defence) or international governance (e.g. United Nations).

\section{[Table 3 about here]}

Table 3 examines the types of site represented in the online anti-war networks. The first five categories may be considered as social movement sites while the latter two are non-movement sites. Each online anti-war network has a broadly similar proportion of movement to non-movement site types, with movement sites making up $90.1 \%, 87.6 \%$ and $94.3 \%$ of the British, US and Australian networks respectively. However, as Table 3 demonstrates, when we look within the broad category of movement sites, we can see some notable differences between the networks. First, within the US network, peace protest sites are dominant while within the British network it is rather peace lobby sites that predominate. Second, category five sites, - alternative media and movement support services - form only a small proportion of the British network (10.3\%) whereas in the US and Australia that category makes up nearly one quarter of the network. Third, within the Australian network it is the wider lobby sites that predominate. While these sites may 
discuss peace issues their goals are firmly directed towards other issues. Many are primarily oriented to environmental concerns and the issue of nuclear power is clearly an important one. Like the peace lobby sites that dominate in Britain, the methods of the groups represented on these wider lobby sites tend to eschew protests and demonstrations, and instead utilise constitutional or informational means for achieving political change. This emphasis on broader concerns in the Australian context can also be seen in relation to the presence of wider protest sites. While all networks contain only a small number of such sites, these are the most numerous in the Australian case.

When comparing sites with transnational linkages (i.e. those situated in the overlap of the three networks) we find that they are more likely to fit into the category of alternative media and movement support services than any of the other site types. The only other category that is more heavily represented (proportionally) in the overlapping zone than outside of it is mainstream media and services. The very fact that many media sites are quite central in these networks points to the desire of movement activists to refer, through their hyperlink practices, to relevant sources of news. The fact that the same news sources are more often found in more than one network than are the various categories of movement site suggests a greater degree of implicit agreement among website authors from each country over which news sources are most relevant, than over which protest or lobby sites are most significant. 


\section{Being Global - Diversity and Solidarity on the Internet}

Our analysis of hyperlinks has highlighted a limited set of international linkages between anti-war movements and a number of characteristic differences between them. The most striking distinctions relate to the Australian network: online it appears only loosely interconnected and is dependent on informational resources provided by anti-war movements in other countries and by the domestic environmental movement. This reflects the 'tyranny of distance' that Capling and Nossal (2001) identified in Australian antiglobalisation activism more generally. As one respondent explained,

It just seems like we're really small and it also seems like we're really disconnected ... we don't have really huge networks, there's not as many people ... you look at any American or European discussions of the global movement and it's like Seattle, Washington, Prague, and it's like, 'hello, hi, down here'. (Aggy interview, Melbourne)

The hyperlink practices of Australian anti-war activists offer an online remedy for a lack of domestic anti-war resources and for the perception of distance from other movements. Describing online connections, however, is far from understanding the degree to which they produce genuine transnational collective action. In the following section of the paper we utilise a qualitative dataset to probe the importance of Internet connections for anti-war activists from each of the three countries. In particular we examine the value placed on online national and international links and how far these map onto offline connections. 


\section{Method}

Qualitative material was collected through in-depth interviews and participant and online observation. Interviews were conducted with activists in Australia shortly before the start of the Iraq war (21 interviews between September 2001 and January 2003) and with British and American activists after three years of war in Iraq (60 interviews between January 2006 and June 2007). Respondents came from a range of organisations that represent a wide diversity in terms of political worldview, activity and scale of organisation .${ }^{5}$ Our analysis of these data focuses on two much-discussed themes particularly relevant in the context of transnational collective action; namely, diversity and solidarity.

\section{$\underline{\text { Imagined Solidarity and Mediated Action }}$}

Initial responses to questions regarding the value of the Internet in campaigning frequently referred to the easy availability of informational resources. Some groups, such as Justice Not Vengeance in Britain, define their primary purpose as exactly to provide such resources for other campaigners (Milan Rai interview, Hastings). Additionally, many respondents referred to morale-boosting benefits of connecting to other anti-war groups online and the desire to find and express solidarity. Following Bayat (2005), we might term this 'imagined solidarity'. Bayat draws on Anderson's work defining the nation as an

\footnotetext{
${ }^{5}$ Groups included: Stop the War Coalition (StWC), Justice Not Vengeance, CND UK, Religious Society of Friends, Faslane 365, Muslim Association of Britain, Muslim Anti-War Network, Respect, Student Islamic Societies, Friends of the Earth Melbourne, Australian Indymedia collectives, Green Left Weekly, Democratic
} 
imagined community 'because the members of even the smallest nation will never know most of their fellow-members ... yet in the minds of each lives the image of their communion' (Anderson 1991, 5).

Imagined solidarity may be achieved through projecting locally grounded actions into the global arena, thereby increasing the significance of a campaign for participants. Interviewees highlighted their ability to communicate their participation in protest:

a lot of the big demonstrations have coincided with demonstrations internationally ... if nothing else - if we don't stop the wars - at least you can hope that word about our actions gets out around the world. (Chris Goodwin interview, Leicester Campaign to Stop the War)

The need to show solidarity was felt most keenly amongst activists who closely identified with those being persecuted in the Iraq war. In Britain this was most obviously represented by Muslim communities and reflects the Islamic concept of one umma; 'the unity, the brotherhood, the sisterhood, of all Muslims, wherever you are, whatever colour your skin is, wherever you live' (Arif Sayeed interview, Islamic Students Society [ISS], Leicester). For some, this extended to a concern for justice for all: 'You stand up for an injustice wherever it is - it doesn't matter whether they're Muslim or not' (Naazish Azaim interview, ISS, Leicester). 
In other instances the Internet was crucial in solidifying activists' experience of acting at the global scale: 'I didn't even know [the movement] existed before I saw it online. That's what politicised me ... the connectedness factor is what made the international days of action' (Nik interview, Melbourne). In Australia, 'we do find internationally that [ICT is] the only way that people get in contact with us and ... that we built up networks of international correspondents have been entirely net based' (Sean Healy interview, Democratic Socialist Party, Sydney). Similarly, 'in the United States the global movement was a source of inspiration for those of us who spoke out. We gained confidence and strength in knowing that we were standing with the vast majority of the world's people' (Cortright, 2004, 29). Each of these examples demonstrates the value of the kinds of symbolic interaction that the Internet is so well suited for; it has facilitated the expressions of solidarity through making available information about protest elsewhere.

A key interchange of expressions of solidarity is in the sharing of news. As noted above the mainstream and particularly alternative media websites dominated the shared space or overlap area between the issue networks across the three countries. Such repetition is no accident. Respondents repeatedly reported frustration with the general lack of coverage of anti-war ideas and activities within much of the mainstream media, making them highly selective in the outlets linked to and promoting the voice of alternative media sources offering more satisfactory coverage. In addition, because media sources were key sites of transnational interconnection we can see the utilisation of these sources as a way of locating local struggles in the global context; that is, in imagining solidarity. A major development here is the way in which the Internet has facilitated the growth of alternative media sources, which were more frequently linked to across the three issue networks than 
mainstream sources. Sites such as Indymedia have become a core medium for interchange between anti-war groups. Again, we see the possibility of imagining solidarity online since the structure of Indymedia is designed to prioritise place-rooted action while offering communication at a global scale (Pickerill, 2007).

\section{Diversity in Collective Action}

Our analysis of website types above shows that the three anti-war networks differed in terms of their activist orientation. Within the US network peace protest sites were most commonly found. Within the British network peace lobby sites predominated and in the Australian network it was wider lobby sites that proved most common, particularly those oriented to environmental concerns. Overall, our findings on website type indicate a degree of political diversity across the networks that supports the arguments concerning the broad basis of contemporary activism in general, and the anti-war movements in particular (Gillan 2006). As an activist in Britain herself noted, 'the anti-war movement has forced some bizarre coalitions' (Yvonne Ridley interview, Respect, London). Participant groups include those committed to ideological pacifism (Society of Friends), feminism (Code Pink), antiglobalisation (Wombles), political parties (Respect), artistic performance (Rhythms of Resistance), and faith (Muslim Association of Britain). Figure 7 displays the physical presence of a range of groups participating together in one demonstration. Similarly, US anti-war coalitions include divisions between goal-focused groups (often informed by variants of Marxism) and process-focused groups from a range of perspectives such as feminism, ecology and civil rights (Firat 2004, 612-14). The key organisations in the Australian anti-war movement have strong environmental and social justice routes 
(Burgman, 2003). For instance, Friends of the Earth, the Australian Greens (Figure 8), Democratic Socialist Party, and Resistance (a socialist youth organisation) all took centre stage in key anti-war demonstrations.

[Figure 7 about here]

[Figure 8 about here]

Activists recognise that incorporating political differences can serve to diffuse and complicate a campaign: 'whenever movements grow... their composition becomes more diverse and more politically uneven, people come with a variety of political consciousnesses, assumptions and experiences, and confusions' (Mike Marqusee interview). Since hyperlinks provide conduits for interested readers to follow from site to site, the diversity of groups linked within anti-war online networks both reflects the diversity found within the offline environment and may serve to enhance and expand it. Tarrow argues that 'all shifting and reticular movements reduce ideological cohesion, but the internet may be extreme in its centrifugal effects' $(2005 a, 138)$. It is possible to see this effect with a positive inflection:

Stop the War is like an umbrella, there's so many small denominations attached to it and they all amalgamate on that web page and from there you get to learn about the anti-capitalist organisations, the gay-rights organisations, the Jews against Zionism organisations. (Arif Sayeed interview, ISS, Leicester) 
Additionally, visual symbols and simple slogans translate easily into different contexts and the Internet certainly provides a plausible avenue for the sharing of symbols (O'Neill 2004, 239-41; Pickerill and Webster 2006).

However, Bandy and Smith express ambivalence about the power of the Internet to provide the basis for coalition building, arguing that face-to-face meetings are more conducive to the creation of trusting relationships (2004, 234). Respondents confirm the view that 'contacts are built on personal networks [and] it's very hard to pass a network on' (Aggy, interview, Melbourne). This illustrates the distinction between hyperlink connections, which cross boundaries with relative ease and the formation of offline transnational collective action, which remains restricted by geographical distance. There is also unevenness between our case countries. The fact that the Australian issue network included more internationally orientated hyperlinks demonstrates an attempt to use information from other countries to create feelings of solidarity; to an extent this may substitute for the far more difficult task of creating more formal transnational coalitions that would require much greater resources.

For all our case countries the diversity of hyperlink connections was not matched by evidence of equivalent offline collaboration. The differences between groups were more divisive than the potential unity of sharing common goals. Thus, for example, formal alliances with the British StWC and the US were not possible because of political differences: '[StWC] wouldn't have done what some parts of the anti-war movement in America has recently done which is... they met representatives from what we regard as a puppet government in Iraq' (Robin Beste, interview, StWC). Such divisions were evident between many groups, but were more acute transnationally where the possibility of 
personal networks and face-to-face meetings through which to build trust were dramatically reduced. Some links were made internationally between disparate grassroots groups and some activists sought to build a decentralised transnationalism but such links remained reliant upon personal ties and rarely crossed ideological differences.

\section{Conclusions}

The foregoing explores the role of ICTs in the process of transnational collective action. We highlight a distinction between the border-crossing hyperlink practices of antiwar website authors and the existence of offline transnational collaboration. While the character of each online issue network was affected by national context, hyperlink structures do reach across both geographical boundaries and a variety of political strategies and foci. This became particularly pronounced in the search for relevant news and commentary from across the globe. The Australian network stood out as relatively highly connected to websites focused on other countries. Online activities create the appearance of diversity of anti-war movements and therefore affect the experience of the movement for those who encounter it on the Web. However, our interviewees noted the lack of face-toface interaction necessary to enhance trust and offered only limited evidence of the sharing of non-informational resources. Consequently, activists' ability to build transnational ties for action was limited.

Online anti-war networks are particularly suited to sharing symbolic expressions of solidarity. It is precisely these symbolic resources that often form the basis of bonds of the (imagined) solidarity that many activists seek. Our analysis of qualitative data asks what 
meaning such connections have for grassroots activists; one respondent summed up this question particularly clearly:

You're wanting a localism, you're wanting a reality and a directness ... but you're interested in the whole world. How do we really become global citizens and what does that mean? What does it mean to know all about what's happening in Italy? (John interview, Sydney)

'Being global' is less about building formal connections between international groups and far more about re-scaling the meaning of local actions to a global audience. This is achieved primarily by articulating a form of imagined solidarity, while simultaneously maintaining the importance of domestic issues. Robin Beste explained that while he used the Internet to scour global sites for information to put on the StWC website - itself examined by Internet users around the world - he considered that 'it's what you do at home that counts' (Robin Beste, interview). Here we can distinguish activists' work as directing flows of information, on the one hand, and the actual mobilisation of opposition on the other. The Internet enables the former to cross national boundaries while the latter remains, for the most part, achieved primarily at national and local scales. This importance of being grounded in place, despite the possibilities the Internet offers, reflects the notion of 'rooted cosmopolitanism' introduced earlier (Tarrow 2005a, 2005b). So, while concrete action remains predominantly affixed to place and to the political context of the nation, Internet connections help activists locate their action within much broader movements. In so far as anti-war websites link to a wide range of worldviews they enable the construction of imagined solidarity. The value of informational linkages does not, therefore, lie in their potential for enabling more formal alliances between organisations (pace Diani 2001). 
Rather, we find that because the sharing of information across borders allows activists to gain a sense of solidarity, Internet networks help the rooted cosmopolitan to feel global.

\section{Acknowledgements}

This research was undertaken through funding provided by the Economic and Social Research Council (UK) for a project on 'Internet Activism: Anti-War Movements in the Information Age' (RES-228-25-0060) and by The Leverhulme Trust (UK) who funded the Australian research. This paper would not have been possible without the invaluable help of all the interviewees. 


\section{Appendix 1 - Websites used as Seed Set for Hyperlink Analysis}

\begin{tabular}{|c|c|c|}
\hline Australia & UK & US \\
\hline www.anti-bases.org & www.j-n-v.org & www.internationalanswer.org \\
\hline www.ajpp.canberra.net.au & www.barewitness.org & www.legitgov.org \\
\hline www.cairnspeacebypeace.org & www.caat.org.uk & www.codepink4peace.org \\
\hline disobedience.nomasters.org & www.cnduk.org & www.space4peace.org \\
\hline www.elaunceston.com/people/PEACE & cndyorks.gn.apc.org/caab & www.iraqpledge.org \\
\hline www.nukefreeaus.org & www.networkforpeace.org.uk & www.michaelmoore.com \\
\hline www.peaceconvergence.com & www.peaceexchange.org.uk & www.mfso.org \\
\hline www.pinegap6.org & www.stopwar.org.uk & www.notinourname.net \\
\hline www.stopwarcoalition.org & www.studentstopwar.org.uk & www.unitedforpeace.org \\
\hline www.vicpeace.org & www.viwuk.freeserve.co.uk & www.veteransforpeace.org \\
\hline www.womenforpeace.org.au & www.faslane365.org & www.votetoimpeach.org \\
\hline
\end{tabular}




\section{References}

Ackland, R. \& R. Gibson, 2006). 'Hyperlinks and horizontal political communication on the WWW: The untold story of parties online.' Virtual Observatory for the Study of Online Networks. URL: <http://voson.anu.edu.au/papers/hyperlinks_polcomm.pdf>. Consulted 17 August 2007.

Anderson, B. 1991. Imagined Communities: Reflections on the Origin and Spread of Nationalism. London: Verso.

Bandy, J. and J. Smith. 2004. 'Factors Affecting Conflict and Cooperation in Transnational Movement Networks.' In Coalitions Across Borders: Transnational Protest and the Neoliberal Order, eds. J. Bandy and J. Smith. Lanham: Rowman and Littlefield.

Bayat, A. 2005. 'Islamism and Social Movement Theory.' Third World Quarterly 26(6): 891908.

BBC. 2003. 'Millions join global anti-war protests.' BBC News Online 17 February 2003. URL: <http://news.bbc.co.uk/1/hi/world/europe/2765215.stm>. Consulted 26 January 2007. Bennett, W. L. 2003. 'Communicating Global Activism: Strengths and Vulnerabilities of Networked Politics.' Information, Communication and Society 6(2): 143-168.

Bennett, W.L. and T. Givens. 2006. 'Communication and Political Mobilization: Digital Media Use and Protest Organization among Anti-Iraq War Demonstrators in the US.' Unpublished manuscript from personal communication.

Berners-Lee, T. 2000. Weaving the Web: The Past, Present and Future of the World Wide Web by its Inventor. London: Texere. 
Bimber, B. 2003. Information and American Democracy: Technology in the Evolution of Political Power. Cambridge: Cambridge University Press.

Burgman, V. 2003. Power, profit and protest: Australian social movements and globalisation. Crows Nest: Allen and Unwin.

Capling, A and K. R. Nossal. 2001. 'Death of distance or tyranny of distance? The Internet, deterritorialization, and the anti-globalization movement in Australia.' The Pacific Review 14(3): 443-465.

Chadwick, A. 2006. Internet Politics: States, Citizens and New Communication Technologies. Oxford: Oxford University Press

Cortright, D. 2004. A Peaceful Superpower: The Movement against War in Iraq. Indiana: Fourth Freedom Forum.

della Porta, D. and M. Diani. 1999. Social Movements: An Introduction. Oxford: Blackwell. della Porta, D and S. Tarrow. 2005. 'Transnational Processes And Social Activism: An Introduction.' In Transnational Protest and Global Activism, eds. D. della Porta and S. Tarrow. Lanham: Rowman and Littlefield.

Diani, M. 2001. 'Social Movement Networks: virtual and real.' In Culture and Politics in the Information Age: A New Politics? ed. F. Webster. London: Routledge.

Firat, A.F. 2004. 'Consuming Activism: Peace, War, And Consumer Research.' Advances In Consumer Research XXXI.

Gillan, K. 2006. Meaning in Movement. An Ideational Analysis of Sheffield-based Protest Networks Contesting Globalisation and War. PhD Thesis, Department of Politics, University of Sheffield. 
GlobalSecurity.org. 2006a. 'Iraq Coalition Forces: Non-US Forces in Iraq - November 2006.' GlobalSecurity.org: Military. URL: <

http://www.globalsecurity.org/military/ops/iraq_orbat_coalition.htm>. Consulted 5 December 2006.

GlobalSecurity.org. 2006b. 'US Forces Order of Battle' GlobalSecurity.org: Military http://www.globalsecurity.org/military/ops/iraq_orbat.htm. Consulted 25 January 2007 Grattan, M. 2006. 'Bring troops home from Iraq now: poll.' The Age, 9 October 2006: URL: http://www.theage.com.au/news/national/labor-surges-as-iraq-takestoll/2006/10/08/1160246013651.html. Consulted 8th December 2006.

Gupta, A. K. 2006. 'Moving Forward: UFPH and the Anti-war Movement.' Leftturn Magazine 19: 64-71.

International Telecommunications Union. 2006. 'Information and Communication Technology Statistics Database.' International Telecommunications Union: ICT Eye. URL: < http://www.itu.int/ITU-D/icteye/Indicators/Indicators.aspx >. Consulted 5 December 2006.

Maney, G., L.M. Woehrle, and P.G. Coy. 2005. 'Harnessing and Challenging Hegemony: The US Peace Movement After 9/11.' Sociological Perspectives 48: 357-381.

Meyer, D. S. and C. Corrigan-Brown. 2005. 'Coalitions and Political Context: US Movements against Wars in Iraq.' Mobilization 10(3): 327-44.

Morrow, J. 2003. 'Australia's Antiwar Movement: Still Marching, but Where?' Worldpress.org 17 April 2003. URL: < http://www.worldpress.org/Asia/1053.cfm>. Consulted 12 January 2007. 
Nah, S., A.S. Veenstra and D. Shah. 2006. 'The Internet and Anti-War Activism: A Case Study of Information, Expression and Action.' Journal of Computer-Mediated Communication 12(1). URL: < http://jcmc.indiana.edu/vol12/issue1/nah.html>. Consulted 5 December 2006. Norris, P. 2002. Digital Divide: Civic Engagement, Information Poverty, and the Internet Worldwide. Cambridge: Cambridge University Press

O’Neill, K. 2004. 'Transnational Protest: States, Circuses, and Conflict at the Frontline of Global Politics.' International Studies Review 6: 233-51.

Pew Research Center. 2003a. America's Image Further Erodes, Europeans want weaker ties. Survey Report. URL: <http://people-press.org/reports/pdf/175.pdf>. Consulted 25 January 2007.

Pew Research Center. 2003b. Views of a Changing World report. URL:<http://peoplepress.org/reports/pdf/185.pdf>. Consulted 25 January 2007.

Pew Research Center. 2007. Broad Opposition to Bush's Iraq Plan. Survey Report. URL: <www.people-press.org/reports/pdf/301.pdf>. Consulted 25 January 2007.

Pickerill, J and F. Webster. 2006. 'The Anti-War/Peace Movement in Britain and the conditions of Information War.' International Relations 20(4): 407-423.

Pickerill, J. 2003. Cyberprotest: Environmental Activism Online. Manchester: Manchester University Press.

Pickerill, J. 2007. 'Autonomy on-line': Indymedia and practices of alter-globalisation.' Environment and Planning A 39. 
Rogers, R. 2002. 'The Issue Crawler: The Makings of Live Social Science on the Web.' The European Association for the Study of Science and Technology Review 21. URL: < http://www.easst.net/review/sept2002/issuecrawler>. Consulted 5 December 2006. Rogers, R. and N. Marres. 2000. 'Landscaping Climate Change: A Mapping Technique for Understanding Science and Technology Debates on the World Wide Web'. Public Understanding of Science 9:141-163.

Rüdig, W. and C. Eschle. 2003. 'Who Demonstrated on February 15? Some preliminary results of a survey of anti-war protesters in Glasgow.' University of Strathclyde, Department of Government. URL: <http://www.strath.ac.uk/government/awp/demo.html>. Consulted 17 January 2007.

Sloboda, J. and B. Doherty. 2004. 'The Human Face of Political Dissent. What we know about the anti-war marchers of February 2003.' Oxford Research Group Briefings. URL:< http://www.oxfordresearchgroup.org.uk/publications/briefings/iraqprotest.pdf>. Consulted 17 January 2007.

Tarrow, S. 2005a. The New Transnational Activism. Cambridge: Cambridge University Press. Tarrow, S. 2005b. 'Rooted Cosmopolitans and Transnational Activists.' Prepared for a special issue of Rassegna Italiana di Sociologia. URL: < http://falcon.arts.cornell.edu/Govt/faculty/Tarrow\%20docs/rooted\%20cosmopolitans.pdf >. Consulted 14 June 2007. 
Table 1: Overview of Three Anti-War Hyperlink Networks

\begin{tabular}{lccc}
\hline & US Network & UK Network & Australian Network \\
\hline No. sites & 96 & 99 & 98 \\
Total network links & 1385 & 1088 & 792 \\
Mean in-link count & & 11.0 & 8.1 \\
In-link count rangec & $5-50$ & $5-36$ & $3-21$ \\
Most central sites & unitedforpeace.org (50) & cnduk.org (36) & unitedforpeace.org (21) \\
(in-link count) & ivaw.net (40) & basicint.org (26) & indymedia.org (20) \\
& veteransforpeace.org (38) & caat.org.uk (24) & iraqbodycount.org (19) \\
\hline
\end{tabular}

\footnotetext{
a 'Total network links' gives the sum of in-links for every site in each network. We are only interested in links between sites within the network so each relevant out-link is also an in-link for one of the other network members. By only counting in-links we avoid double-counting. For each network the maximum possible total network links = no. sites $\mathrm{x}$ (no. sites - 1).

$\mathrm{b}$ 'Mean in-link count' is simply the ratio of total site-to-site links to the number of sites in the network and therefore represents the density of connections. For each network the maximum possible mean in-link count = no. sites -1 .

c 'In-link count range' gives the lowest and highest number of in-links received by one site in the network.
} 
Table 2: Locale Compared Across National Networks and Network Overlap (figures in parentheses are \%) ${ }^{a}$

\begin{tabular}{lccc|ccc}
\hline & \multicolumn{3}{c|}{ By Network } & \multicolumn{3}{c}{ By Site Position } \\
& & & & Non- \\
Overlap & overlap & \\
Locale & US & UK & Australia & Sites & Sites & All Sites \\
\hline US & $86(91.5)$ & $12(12.2)$ & $23(24.7)$ & $19(54.3)$ & $78(38.0)$ & $97(40.4)$ \\
UK & $2(2.1)$ & $51(52.0)$ & $4(4.3)$ & $5(14.3)$ & $46(22.4)$ & $51(21.3)$ \\
Australia & $0(0.0)$ & $0(0.0)$ & $39(41.9)$ & $0(0.0)$ & $39(19.0)$ & $39(16.3)$ \\
Other National & $0(0.0)$ & $3(3.1)$ & $10(10.8)$ & $2(5.7)$ & $9(4.4)$ & $11(4.6)$ \\
Focus & & & & & \\
International & $6(6.4)$ & $32(32.7)$ & $17(18.3)$ & $9(25.7)$ & $33(16.1)$ & $42(17.5)$ \\
\hline Totals & 94 & 98 & 93 & 35 & 205 & 240 \\
& $(100 \%)$ & $(100 \%)$ & $(100 \%)$ & $(100 \%$ & $(100 \%)$ & $(100 \%)$ \\
\hline
\end{tabular}

a All websites where the locale was identifiable were included; 8 cases were unidentifiable. 
Table 3: Website Types Compared Across National Networks and Network Overlaps

(figures in parentheses are \%)

\begin{tabular}{|c|c|c|c|c|c|c|}
\hline & & By Network & & & By Site & \\
\hline Website Type & US & UK & Australia & Sites & Sites & All Sites \\
\hline Peace Protest & $25(27.2)$ & $24(24.7)$ & $18(20.0)$ & $7(20.6)$ & $51(25.4)$ & $58(24.7)$ \\
\hline Peace Lobby & $13(14.1)$ & $33(34.0)$ & $12(13.3)$ & $7(20.6)$ & $43(21.4)$ & $50(21.3)$ \\
\hline Wider Protest & $5(5.4)$ & $5(5.2)$ & $12(13.3)$ & $2(5.9)$ & $18(9.0)$ & $20(8.5)$ \\
\hline Wider Lobby & $20(21.7)$ & $13(13.4)$ & $22(24.4)$ & $6(17.6)$ & $41(20.4)$ & $47(20.0)$ \\
\hline $\begin{array}{l}\text { Movement Media } \\
\text { and Services }\end{array}$ & 20 (21.7) & $10(10.3)$ & $21(23.3)$ & $9(26.5)$ & $28(13.9)$ & $37(15.7)$ \\
\hline Mainstream Media & $5(5.4)$ & $2(2.1)$ & $2(2.2)$ & $2(5.9)$ & $5(2.5)$ & $7(3.0)$ \\
\hline Governance & 4.3 & $10(10.3)$ & $3(3.3)$ & $1(2.9)$ & $15(7.5)$ & $16(6.8)$ \\
\hline \multirow[t]{2}{*}{ Totals } & 92 & 97 & 90 & 34 & 201 & 235 \\
\hline & $(100 \%)$ & $(100 \%)$ & $(100 \%)$ & $(100 \%)$ & $(100 \%)$ & $(100 \%)$ \\
\hline
\end{tabular}


Figure 1: No WMDs = No Need for War, London, March 2006a

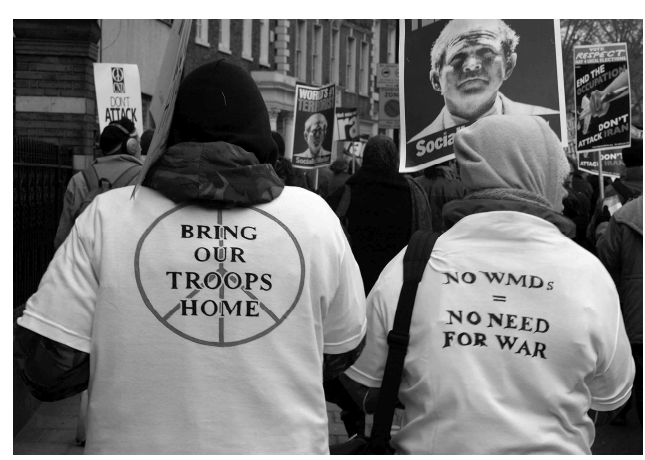

a All photographs taken by Jenny Pickerill. 
Figure 2: Multiple messages from the Stop The War Coalition, London, March 2006

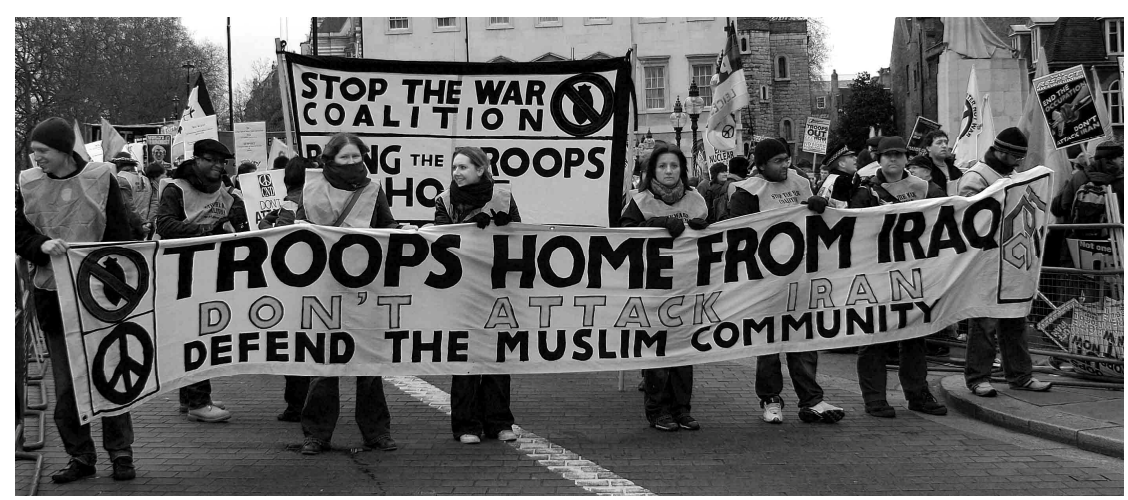


Figure 3: Poster 'Anti-Muslim Racism: The True Face of the War on Terror', Melbourne, August 2005

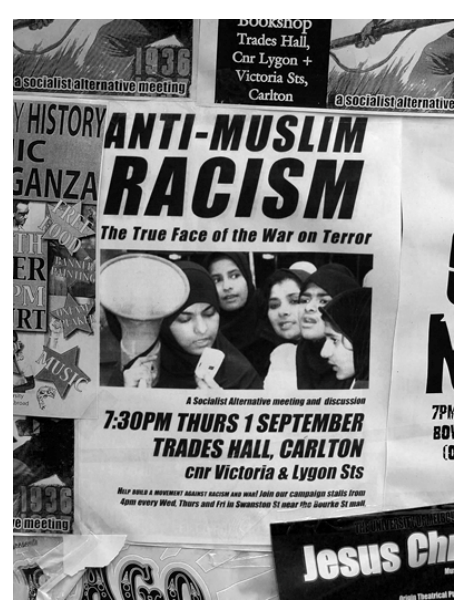


Figure 4: 'Dissent is Patriotic' sign in a building overlooking Twin Towers site, New York City, April 2005

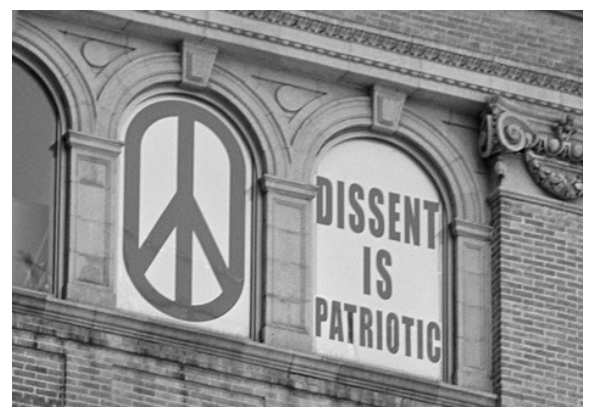


Figure 5: Quaker 'Prayers for Peace', a ribbon for every US soldiers' death in Iraq, New York City, April 2006
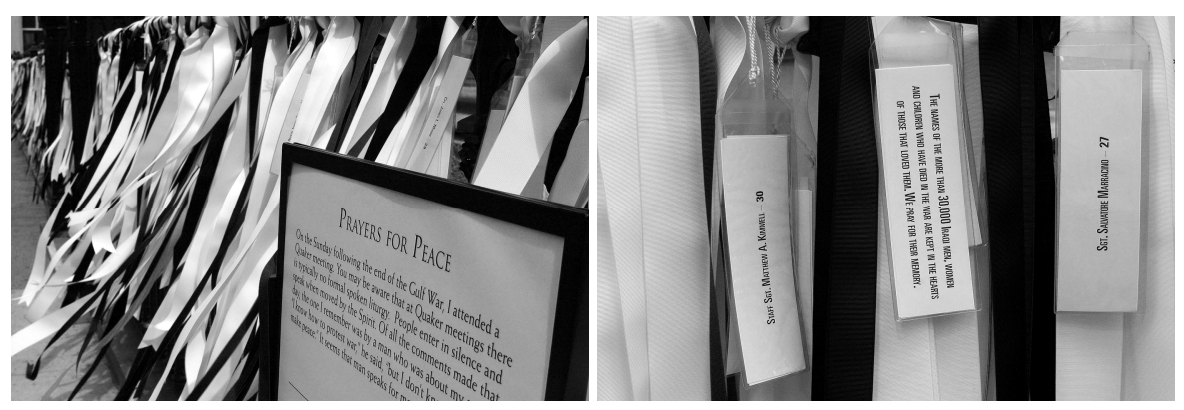
Figure 6: Proportional Venn Diagram Representing Network Overlapa

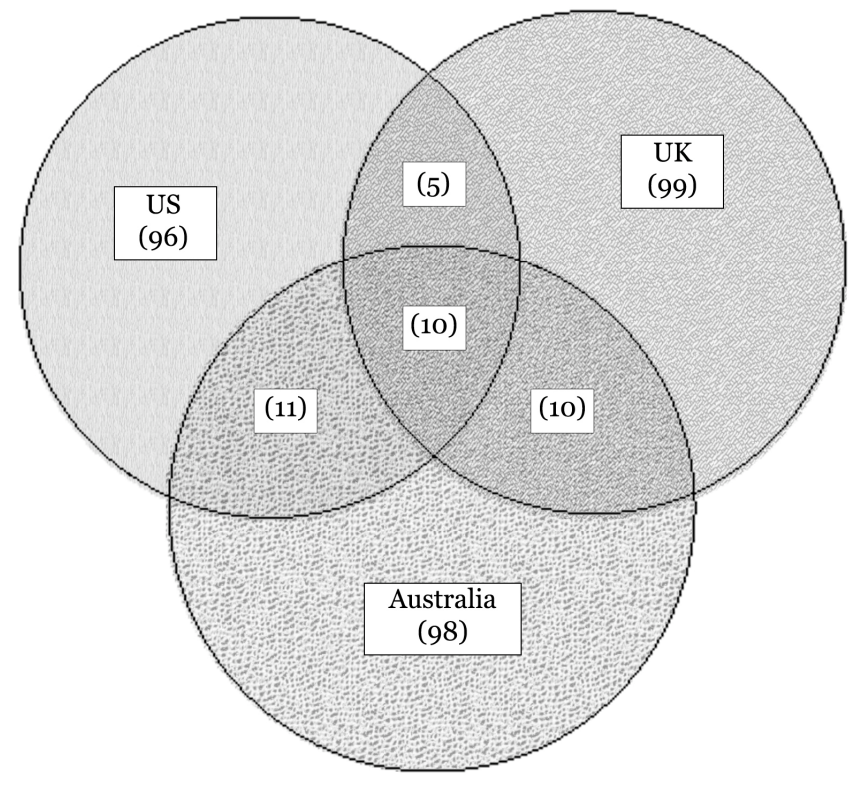

a Areas represent approximate proportionality, calculated using online software made available by Peter Rogers,University of Kent. URL:

<http://www.cs.kent.ac.uk/people/staff/pjr/EulerVennCircles/EulerVennApplet.html>. Consulted 17 January 2007. 
Figure 7: Multiple Messages: Placards from Muslim Association of Britain, Green Party and Campaign for Nuclear Disarmament, London, March 2006

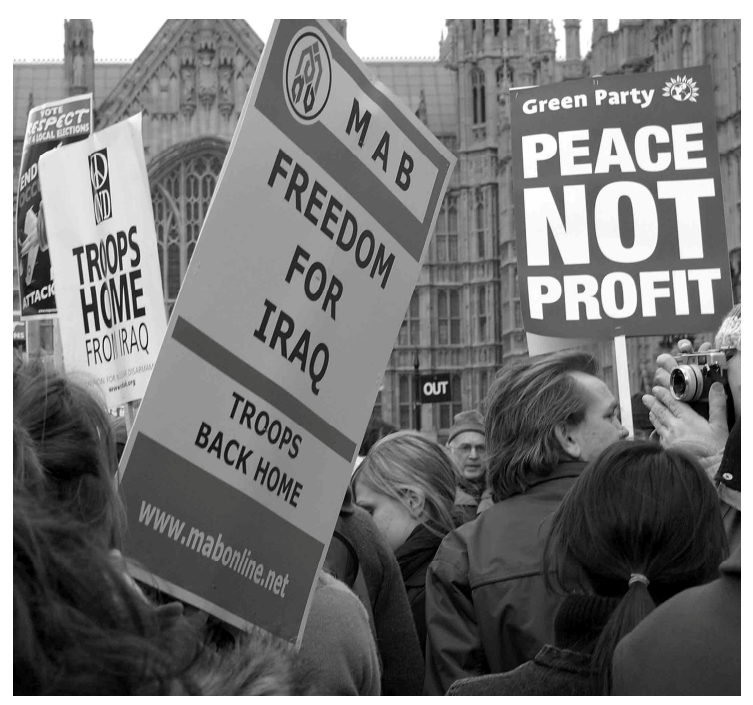


Figure 8: Australian Greens website, December 2006

Note prominence of 'No War on Iraq' photo.

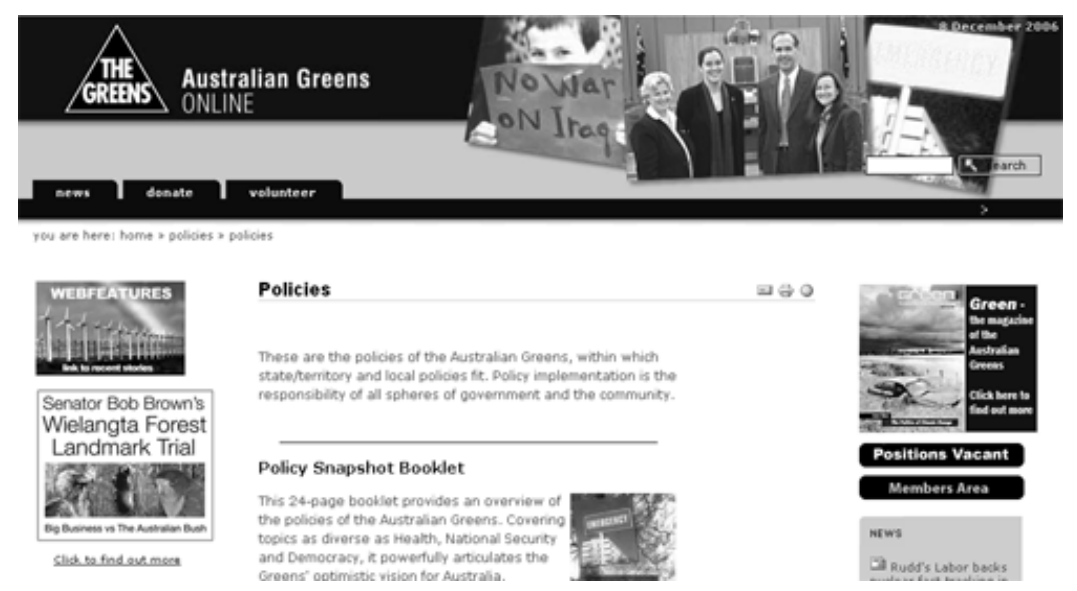

